\begin{abstract}
Iranica
Abstracta Iranica Revue bibliographique pour le domaine irano-aryen

Volume 32-33 | 2013

Comptes rendus des publications de 2009-2010
\end{abstract}

\title{
Marie-Anne Vannier (éd.). Connaissance des Pères de l'Église. Isaac de Ninive
}

\section{Christelle Jullien}

\section{(2) OpenEdition \\ 1 Journals}

\section{Édition électronique}

URL : http://journals.openedition.org/abstractairanica/40842

DOI : 10.4000/abstractairanica.40842

ISSN : 1961-960X

Éditeur :

CNRS (UMR 7528 Mondes iraniens et indiens), Éditions de l'IFRI

\section{Édition imprimée}

Date de publication : 1 décembre 2013

ISSN : 0240-8910

\section{Référence électronique}

Christelle Jullien, « Marie-Anne Vannier (éd.). Connaissance des Pères de l'Église. Isaac de Ninive », Abstracta Iranica [En ligne], Volume 32-33 | 2013, document 328, mis en ligne le 01 juillet 2016, consulté le 26 septembre 2020. URL : http://journals.openedition.org/abstractairanica/40842 ; DOI : https://doi.org/10.4000/abstractairanica.40842

Ce document a été généré automatiquement le 26 septembre 2020.

Tous droits réservés 


\title{
Marie-Anne Vannier (éd.). Connaissance des Pères de l'Église. Isaac de Ninive
}

\author{
Christelle Jullien
}

\section{RÉFÉRENCE}

Marie-Anne Vannier (éd.). Isaac de Ninive. Paris, Éditions Nouvelle Cité, 2010, 64 p.

(Connaissance des Pères de l'Église 119).

1 Ce petit fascicule réunit cinq contributions sur Isaac de Ninive, dit le Syrien $( \pm 640- \pm 700)$, dont l'œuvre, l'un des monuments de la littérature ascétique et mystique syriaque, eut une influence importante sur le christianisme en Orient. Sont retracées sa biographie et sa place dans la spiritualité syriaque, tout comme la réception de ses écrits, les grandes orientations de sa doctrine ascétique; quelques thématiques ascétiques sont présentées. Signalons une brève et intéressante étude sur le couvent de Rabban-Šābuhr dans le Huzistan, où Isaac vécut ses dernières années, couvent dont le rayonnement fut exceptionnel sur tout le sud baylonien et les régions du Golfe.

\section{AUTEURS}

CHRISTELLE JULLIEN

CNRS, Mondes iranien et indien, Paris 